\section{P-369 Sildenafili台療抵抗例および慎重投与例に対 する臨床的检討}

\begin{abstract}
大阪市立大学 医学部 ${ }^{1}$ 大阪市立十三市民病院 ${ }^{2}$
出中智章 ${ }^{1}$ 桑原 (伸介 ${ }^{1}$ 長沼俊秀 ${ }^{1}$ 甲野拓郎 ${ }^{1}$ 川嶋秀紀 ${ }^{1}$ 岸本武利 ${ }^{1 /}$ 桝时 周佳 ${ }^{2}$ 西阪誠泰 ${ }^{2}$ 安本 亮二2)

日的】本邦に扔いても、SildenafillED外来に扔ける主要な治療才 プションとなってきた。さらにSildenafil治潦抵抗例および慎重投 施が必要な症例人の対応が望まれる。自駼例に扔いて臨床的検討 を行った。【対象と今法】分類は機能性5例、血管性 2例、神経性3 例、糖㽷病性.1例、さらに血液透析例6例である。Sildenafil治療抵 抗例に対して（1）用量增加、（2）ICI（PGE 1) 併用を行い、 またHD例に対しては（1）ICIによるトレーニング、（2） Sildenafil使用を行った。【結果】用量增加の効果は $25 \mathrm{mg} \rightarrow 50 \mathrm{mg}$ (有 効：3/5)、50mg $\rightarrow 75 \mathrm{mg}$ (有効：1/1)、50mg $\rightarrow 100 \mathrm{mg}$ (有効：3/3)で あった。Sildenafil 50mg + ICl (PGE1)は2 例に行い1 例は著効した。 HD 3例に対してICl (PGE1または塩酸パパベリン) によるトレーニ ングを行い、いずれも合併症なく2例が有効であった。さらに重 篤な循環器合併症を認めなかったHD 3例に対してSildenafil $25 \mathrm{~m} \mathrm{~g}$ を投与し、副作用認めず有効であった。結論】 Sildenafi抵抗症例 に対する用量增加および ICI併用療法は有効な手段と考えられた。 HD例に対してはICIは選択しうるオプションと考えられた。
\end{abstract}

Sildenafil dose-up PGE1

\section{P-371 Initial Experience with MUSE*}

\author{
Urology Department, The North Middlesex Hospital ${ }^{1)}$ \\ Fowlis George $^{1 /}$ Vohra Anil ${ }^{1)}$ Daswell Rosemarie ${ }^{1)}$ Mcdonald \\ Jean ${ }^{1)}$
}

【Introduction】 Erectile dysfunction is an increasing problem as patients become more aware of available treatments. We describe our experience with MUSE*. 【Materials \& Methods】 149 patients attending our outpatient clinic opted for MUSE* therapy. They were initially titrated to an optimal dose, following which the need the medication unsupervised. Follow up data was obtained at 3,6 and 12 months, using a sexual health questionnaire. [Results] 86 patients $(57.7 \%)$ remained satisfied with MUSE*, obtaining grade 4-5 erections suitable for sexual intercourse. 15 patients $(10.1 \%)$ had poor response. 48 patients $(32.2 \%$ ) failed to continue treatment for a variety of reasons. [Conclusion] MUSE* therapy achieves moderate success but appears to have improved patient satisfaction. It is less invasive and can be used at high dose. Our initial results are encouraging and we feel this is a cost effective option in the trearment of erectile dysfunction. $* O+R$

Erectile dysfunction Treatment MUSE
P-370 当科におけるクエン酸シルデナフィル治療

\section{東邦大学 医学部 第一泌尿器科 1 ? 博慈会記念総合病院 ${ }^{2)}$}

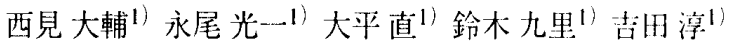

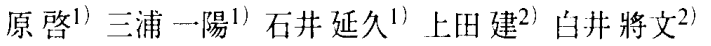

【目的】勃起障害(ED)の治療はシルデナフィルの队服が第一拱抓に なりED誩療が一変した。そこでシルデナフィル治䝤の現沉を明ら かにすることを目的とした。【対象とす法】対象は壮成11年3月23 日から9月30日の約6力月間に東邦大学大森病院りプロダクション センターを訪れたED患者375例とし、投与方法は日本性機能学会 ガイドラインやファイザー製薬社製の使用!:の注意書にしたがっ て行った。結果】シルデナフィルの使用患者数は204例でED患考 の54.4\%であった。使用患者の年歯は20８0歳、平均44.5墄、パー トナーの年齢は19－75歳、平均40.6藏であり、ED期間は0.17４1集、 平均6.0年であった。経過観察できたのは89例 $(43.6 \%)$ で㑉人輸 入や近医での継続が考えられた。89例の成績は斗均で性父の試み 頻度（月）は1.7回から4.5回に增加し、腔内㨂人摔は $29.5 \%$ 只ら $83.7 \%$ に、胵内射精率は $21.6 \%$ から $77.5 \%$ に改善した。改善例の制

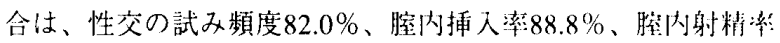
$77.5 \%$ 、勃起の改善96.6\%であった。副作用は䁰痛6例 $6.7 \%$ 、顔の ほてり 5 例 $5.6 \%$ 、動悸など4例 $4.5 \%$ 、消化器症状 3 例 $3.3 \%$ 、眼の披 れなど2例2.3\%でいずれも軽症で一過性で中止する患者はいなか つた【結論】シルデナフィルは安全性、有效性が嵒くED治将に 有用な薬郕と考えられた。今後症例を增やして報简したい。

勃起障害(ED) シルデナフィル 有効性と安全性

\title{
P-372 先天性異所性精巣ラットにおける造精機能 障害、
}

\begin{abstract}
帝京大学 医学部 泌尿器科 ${ }^{1}$ 帝京大学 医学部 病理学 教室 ${ }^{2}$ 帝京大学 医学部 中央動物室 ${ }^{3}$

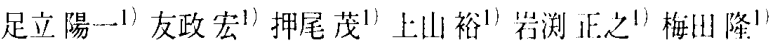
入江宏 ${ }^{2}$ 田村弘 ${ }^{3}$

【目的】精巣下降異常による造精機能障害のモデルとして考えら れている先天性異所性精巣ラット（TS strainラット）を朋い、精細 管上皮の障害を検討した。【方法】雄の約 $70 \%$ に洒側ないしは側 の精巣下降異常が認められるTS strainラットのうち片側買所吽精渠 のものを用いた。患側精巣は鼠径管通過後反転し、生後利3遠川 で鼠径部の皮下、腹壁笳層の表面に触知されることが確誑されて いる。生後4週、6週、8週でそれぞれ4几てづつを用い、精巣禹星、 精巣組織、精細胞のアポトーシスを検捨した。組織学的検藏には Hematoxyline-Eosin染色を、アポトーシスの検出にはTUNEL法を用 い、陽性精細管数および陽性細胞数を検詂した。対側の㓌豪肉精

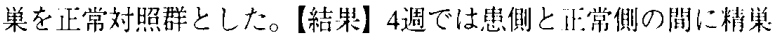
重量に差はなく、精細胞の一部にアポトーシスをみとめた。6䢙 では患側の精巣重量が正常側に比較して約40\%に減少し、組織兴 的に精上皮細胞の減少が認められ、精轨細胞を中心にアポトーシ スの増加が観察された。8週では患側の精巣重量は正常側に比洨 して約 $30 \% に$ に減少し、組織学的に高度の精細管の萎縮を热めた。 【結論】今回検討したTS strainラットに扔いてアポトーシスが造精 機能障害に強く関尗ていることが示唆された。
\end{abstract}

異所性精巣 精細胞アポトーシス ラット 